\title{
First Generation Students in the Hungarian Higher Educational System
}

\author{
Veronika Bocsi ${ }^{1}$ \\ Recommended citation: \\ Bocsi, V. (2020). First Generation Students in the Hungarian Higher Educational System. Central European \\ Journal of Educational Research, 2(1), 53 - 65.
}

\begin{abstract}
The first part of the study attempts to summarise the most frequently used and cited theories and empirical findings in the field of first generation students. The specialist literature has identified those factors (cultural background of family, parents' special attitude toward learning, the features of the time-budget etc.) which can generate a disadvantageous situation within the higher education system for these students. However, the presence of this group is a significant indicator of the openness of a society and social mobility, and a more careful analysis of this population may reduce the drop-out rate, as well. During the empirical analysis two databases were used (Eurostudent VI, Hungarian Youth Research 2012 and 2016). Our results draw attention to the process of social closure and the decreasing chance of attending higher education for young people from lower social groups. This unfavourable shift can mirror the relatively closed features of Hungarian society, but at the same time it can make the distances among social groups more rigid.
\end{abstract}

Keywords: higher education; first generation students; social inequalities

\section{Introduction}

The aim of the study is to give an overview of the main features of first generation students in the Hungarian higher educational system. Two databases will be analysed (EUROSTUDENT VI and Hungarian Youth Research 2016) and these databases allow us to discover the participation rate of these students, the main sociocultural features (parental educational level with 10 categories, classification of parents, type of settlement), and some special elements of their learning process (study related time budget, attitude toward further learning). These empirical findings must be interpreted from the perspective of educational sociology, so we will reflect on both the nature of Hungarian society and the educational system.

\subsection{First generation students (features, theories and socialisation)}

Since the end of the 20th century the issue of intellectuals has become more and more popular in the field of social sciences. The most popular schools have tried to describe the changed roles of intellectuals in today's transformed social circumstances (the effects of postmodernity, the effects of the mediatized world etc. - Reul 2005, Hudson 2005, Bauman 1995, Jacoby 2000, Haney 2008), but from the viewpoint of educational sociology the relationship between higher education and intellectuals seems to be more intriguing. The transformation of the universities (Bok 2000, Graham 2005, Marginson 2007, Lagermann and Lewis 2012, Fitzgerald, White and Gunter 2012) can form the attitudes, the behaviour and the practices of would-be-intellectuals. The whole educational system has been transformed, in part due to the process of expansion. The features of the student population have been altered (the proportion of the so-called non-traditional students has risen), as has the population of lecturers or academics.

1 University of Debrecen, Debrecen, Hungary; bocsiveron@gmail.com 
The academic literature makes a distinction between first generation students and working class students, but there is a significant overlap in the case of these two groups. The starting point of the first approach is the educational level of the parents and in the latter case it is the category of the parental profession and the lack of a degree (Lightweis 2014). In this paper, we mainly use the first approach, for methodological reasons. On the one hand we were able to separate the subsample of first generation students more easily ${ }^{2}$ and the limits of the populations seemed to be clearer to us; on the other hand, this analysis is a part of a wider research project which focuses on the relationship between the training of intellectuals and the current higher education system in Hungary.

The situation and features of first generation students seems to be a very significant issue from the perspective of social mobility. Higher education can function as a ladder towards a higher class but there are a lot of barriers which restrict this opportunity and shape the participation rate. Some training courses (e.g. teacher training) have always offered more opportunities for those young people who come from the lower social groups but these professions cannot generally be linked to a higher level of prestige. Moreover, this fact (the relationship between social mobility and higher education) evolves a special, instrumental attitude toward higher education where university or training courses can be useful tools for social mobility (Burlutskaia 2014).

The circumstances of entry, the available scholarships and student loans, the level of the tuition fee and students' living costs shape the chances for the first generation students. The role of mentors, career advisors, academics and staff is very significant (Christie 2016, Tiele et al. 2017). All these people must be aware of the fact that the university is a "strange land" for these students (Oldfield 2012). Experts draw attention to the lower chances of entering a higher education institution, which can make the structure of a society more rigid and the extent of social mobility less significant (Reay, Crozier and Clayton 2010, Haveman 2006, Tiele et al. 2017). Moreau and Leathwood (2006) argue that the lack of an institutional policy (and an educational policy) can accelerate the growth of social inequalities.

The expansion of the higher education system shapes these patterns as well, but scholars highlight that the essence of the process remains unchanged. Although the expansion has increased the participation rate of first generation students, the persistence presence of these groups is less significant, their pre-college characteristics have special features (Pike and Kuh 2005) and their educational aspirations seems to be less noticeable (Terenzini et al. 1996). Middle-class students have advantages in this competition due to the different forms of parental capital (cultural, social and economic) and the special parental attitudes toward their children's schooling (Cooper 2013). When educational sociology tries to describe this situation it generally uses the phenomena and theories of Bourdieu or improves his concepts (Soria and Bultman 2014). For example, Reay, Crozier and Clayton (2010) used the "institutional habitus" and "institutional cultural capital" phenomena when they analyse the situation of working class undergraduates in the UK. From this viewpoint student life is a sharp change for these young people because they do not have earlier knowledge about higher education and they do not ask help from their parents or peers. They have to learn new and strange norms, language and behaviour and this process starts a change in their identity (Reay, Crozier and Clayton 2010). The result can sometimes be a mixed pattern of identity but the special literature mentions the phenomenon of a lost or hidden working class identity, as well (Pearce, Down and Moore 2008). Weidman (2006) summed up the theories and the process of students' organizational socialisation on campus. In the case of the first generation students different inputs, different processes and different outputs can be found. The disadvantages can shape the students' opportunities on the labour market, as well.

Both qualitative or quantitative research highlights the disadvantages of first generation students in the system of higher education and these elements can be explained by pre-college factors on the one hand, and issues with advancement inside the university campus, on the other. Some elements belong to the latter group, such as a low level of university integration, which refers to peergroup networks and relationships with lecturers (Rubin and Wright 2015). These students have fewer opportunities for paid or volunteer work which is connected with the field of study (Moreau and

\footnotetext{
${ }^{2}$ The parental educational level is an eligible independent variable on the website of Eurostudent VI.
} 
Leatwood 2006) and thus are less involved in extra-curricular activities on campus (Lehmann, 2012, Laemmli, 2011).

Due to the educational expansion differences have become more and more visible among institutions, and the distances between the institutional habitus and the cultural background of first generation students can be more significant. The change of identity can be more drastic and these students have reported that they have experienced missing elements in many fields. Some research projects describe the situation of first generation students in high prestige campuses (Laemmli, 2011, Tiele et al. 2017).

\subsection{The Hungarian Situation}

As we have mentioned, the system of higher education has always ensured the chance of social mobility - but to different extents at different times. Between the two World Wars, Hungarian society was rather closed and every social group had their own special type of school and educational career path. Karády (2012) analysed the relationships in the social group of intellectuals, social mobility and higher education. He stated that some disciplines were more open (at the lower level of teacher training, theology and agriculture) but the disciplines with higher prestige could mainly attract students from the middle and upper-middle classes.

The higher educational system during the Kadar-era had elitist and closed features and the political control was strong, whereas the presence of a market mechanism was not significant. The socialist system tried to restrict the access children of intellectuals had during the preliminary process but this restriction was not entirely successful - moreover, the proportion of first generation students was higher than earlier. Society became more closed during the $80^{\prime} \mathrm{s}$, inequalities started to rise at a slow pace and the different groups from the upper strata started their social reproduction - and education was a possible way to help this process. ${ }^{3}$ During the $80^{\prime}$ s the proportion of working class students fell at the universities (Romsics 2017).

The mass higher education system started to emerge in the 90's in Hungary (Kozma, 2004, Hrubos 2014). This change can be explained by the national educational policy, the funding of institutions and the increased social demand for higher education. The earlier restricted regulation ended after the regime changed, but certain external conditions made tertiary educational less available. The expansion increased the proportion of non-traditional and first generation students especially in case of part-time courses. The diversification of the higher education system became significant as well, and, if we analyse the social background of the student population, we can therefore detect sharp differences between institutions and training programs. Hungarian empirical research has revealed the features of first generation students or undergraduates from disadvantageous backgrounds (Hrubos 2012, Berlinger and Megyeri 2015). To sum up, in these findings we can identify those segments of the system in which this population is overrepresented (bachelor courses, and specific disciplines e.g. teacher training, agronomy, art and humanities). Some institutions have a student population with a more disadvantageous social background because of their location and catchment area. ${ }^{4}$ In the last decade the process of expansion has appeared to stop, although explanations for this are very complex and not clear-cut. First of all, the changes could be due to the demographic situation and the waning number of the young. Secondly, it could be caused by the educational policy (altering of preliminary requirements, the charges in the courses offered, etc.). The transformation of learning motivations and plans can be detected with the help of nationwide quantitative research. The findings showed that the proportion of young people who were planning further studies in HE decreased from 2012 to 2016 (Bocsi 2018).

\footnotetext{
${ }^{3}$ The most frequently used theories which tried to describe the society of the 80 's generally used Marxist categories (Kolosi 1987, Szelényi 1990) and with the help of these theories the different middle class groups could be identified. Kolosi used two axes (redistribution and the market). Romsics (2017) stated that the educational level of the political elite rose in the late Kádár-era.

${ }^{4}$ The proportion of students from a disadvantaged background is highest at the University of Debrecen (Hegedüs 2018). This institution is located in the eastern part of the country and its catchment area includes the Hungarian minority population outside the Hungarian borders.
} 
The proportion of first generation students remains closely linked to the openness of a society and its social mobility. Therefore, Hungarian society is more closed rather than opened (Eurofound 2017), making the increase in the number of these undergraduates a very important issue from the perspective of inequality. This closed feature can be explained not only by the features of higher education but by the structure of the whole educational system as well. According to the PISA test results, we can state that the level of the resilience is low and the effects of parental background on children's school achievement are significant at the same time (Hungary. Student Performance 2018). The structure of Hungarian public education can fix the rather rigid structure of society because it is a selective system with different educational career paths, institutions and school maintainers (Csapó and Kinyó 2009). The career paths of children divorce each other in the early stage of childhood and the destinations of these paths are diverse.

\section{Research design and Methods}

During this analysis two databases were used. With the help of Eurostudent VI cross-section statistics we used the website of the research project (Eurostudent 2016). ${ }^{5} 28$ countries took part in this research between 2015 and 2018. The Hungarian sample contains data from 25 institutions and the number of respondents was 7202. They were active students in the Spring semester of 2015/16 (both full and part time students). They had to fill out the questionnaire in an online form. Means and percentages were analysed, due to the fact that we only used the website of the research and not the database. With the help of the variable of "educational attainment of students' parents" we can identify undergraduates without parents with higher degrees (ISCED level 0-4, N=3240). The analysed fields were the following: proportion of first generation students, the type of training course, the fields of disciplines, economic capital, attitude toward learning, time budget, educational plans, study intensity and the reason for interruption.

The Hungarian Youth Research project is a nationwide analysis carried out in Hungary since 2000. The fifth wave was conducted in 2016. The respondents were 8000 young people between 15 and 29 years old and the database is representative by gender, country and the types of settlements. 6 We could identify the subsample of full-time students and describe the population, and compare the differences between the situation in 2012 and 2016 in terms of first generation students. With the help of the parental classification we wanted to identify not only the first generation students but working class students, as well. We have analysed the parental educational level, the classification of parents and the type of the settlement. In this case we can identify the mixed parental background too (one parents has got a degree and the other has not).

Of course, we are aware of the fact that these two subsamples are not equivalent, but we attempt to analyse them from different perspectives and highlight the longitudinal trends in the second case.

\section{Results}

\subsection{Eurostudent VI}

The proportion of students with parents without a higher education background is $45.4 \%$ in the Hungarian sample. The highest proportion is found in Turkey, Austria, Italy and Portugal (above 60 percent) and the lowest in Norway. Of course, this proportion was shaped not only by the selectivity of the educational system but the educational level of the adult population and the extent of the part time population, too. The proportion is higher in the case of bachelor students (47\%) than those on master courses $(44 \%)$. If we analyse the features of the subsample without any parental tertiary educational level, we can see that part time students and women are over-represented. Fényes (2009) described the gender equalities in the Hungarian higher education system and said that men have a higher level of cultural and economic capital, so young men from a lower strata tend to choose paid work and professional training instead of higher education. Moreover, the level of social mobility in

\footnotetext{
5 We used the 'all country' or 'Hungary' options and the topic 'educational attainment of students' parents'.

${ }^{6}$ We received the rights of use of the database from Kutatópont.
} 
the case of women is generally higher than with men, so women have a specific attitude toward higher education and they use it as a tool in their mobility process (Eurofound 2017).

The levels of economic capital are obviously different if we compare these two subsamples. In Eurostudent VI the level of subjective economic capital was measured, and the comparison gives us the relationship assumed earlier (i.e. the "not well off" and "not very well off" categories are more typical in the case of first generation students).

The first diagram shows the patterns of the field of study.

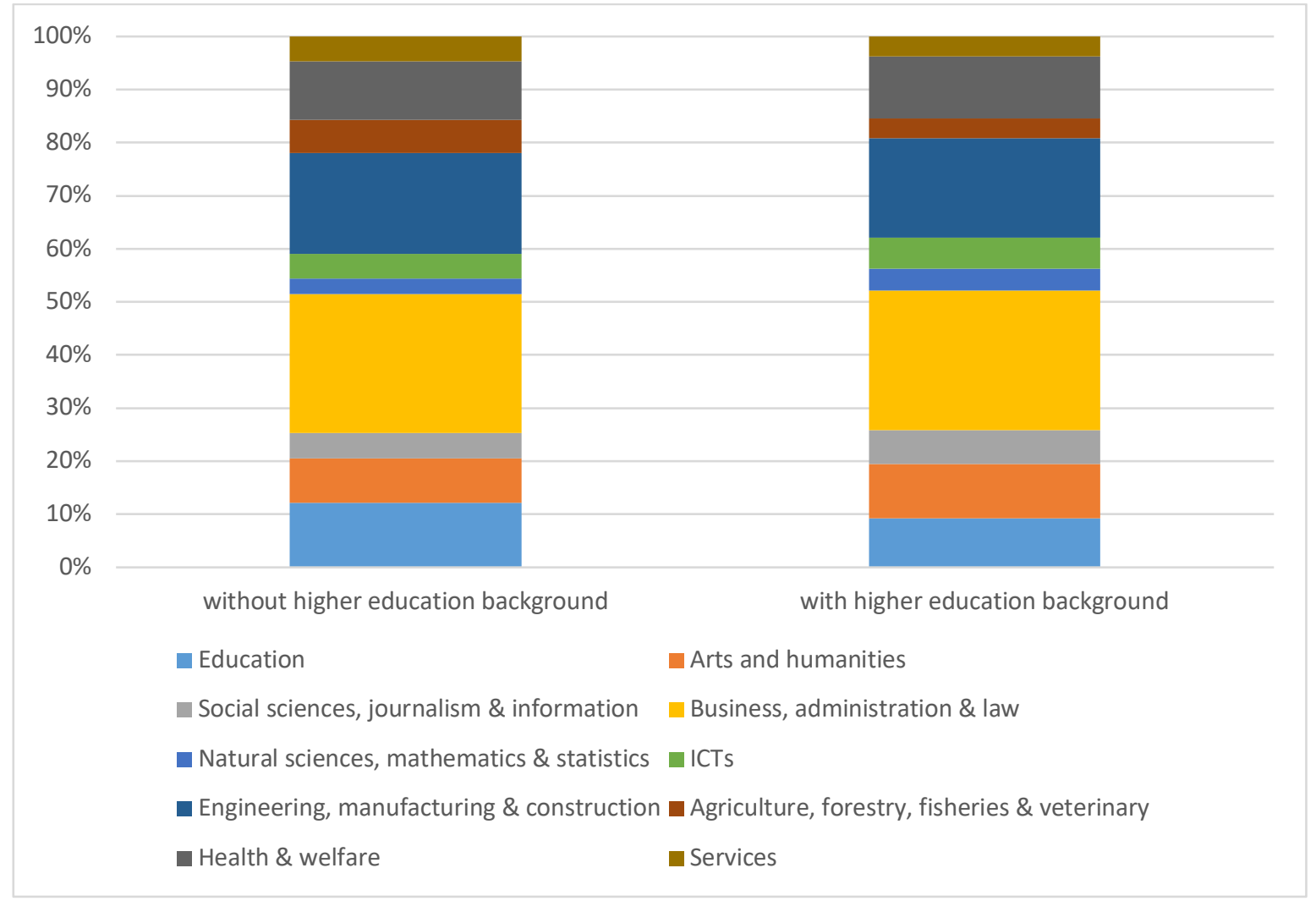

Diagram 1. Fields of study according to parental educational level (Eurostudent VI, percents, N=7202)

Professions or jobs can determine the social position of individuals. It is a frequent situation that a family tries to reserve its social position by the younger generation choosing a course with higher prestige (e.g. medicine, law etc.). If we go through the different courses, we can see that some categories are complex: for example, "Health and welfare" includes both medical training courses and the training of nurses. Access to higher prestige training seems to be very complicated for young people from lower social groups due to higher preliminary requirements and financial burdens. First generation students are overrepresented in the field of education and agriculture in Hungary - we have seen that these were the typical routes of first generation students before World War II, as well.7 The prestige of teachers is generally lower in Hungary (Tímár and Polónyi 2006) and this can affect the social base of these training courses, too.

With the help of Eurostudent VI, educational pathways, attitudes toward learning, the time budget and the interruption of the course were analysed, as well. The special literature pointed out that first generation students have a peculiar attitude toward learning and their lifestyle shows another sort of pattern, due to their material circumstances. If we analyse the time budget of first generation students, interesting differences can be identified (Diagram 2). Undergraduates had to estimate how much time they spent on study-related activities from their total time budget.

\footnotetext{
${ }^{7}$ If we compare the patterns of the 28 countries, different over-represented fields can found - education is typical in almost every country - but there are exceptions in some cases.
} 


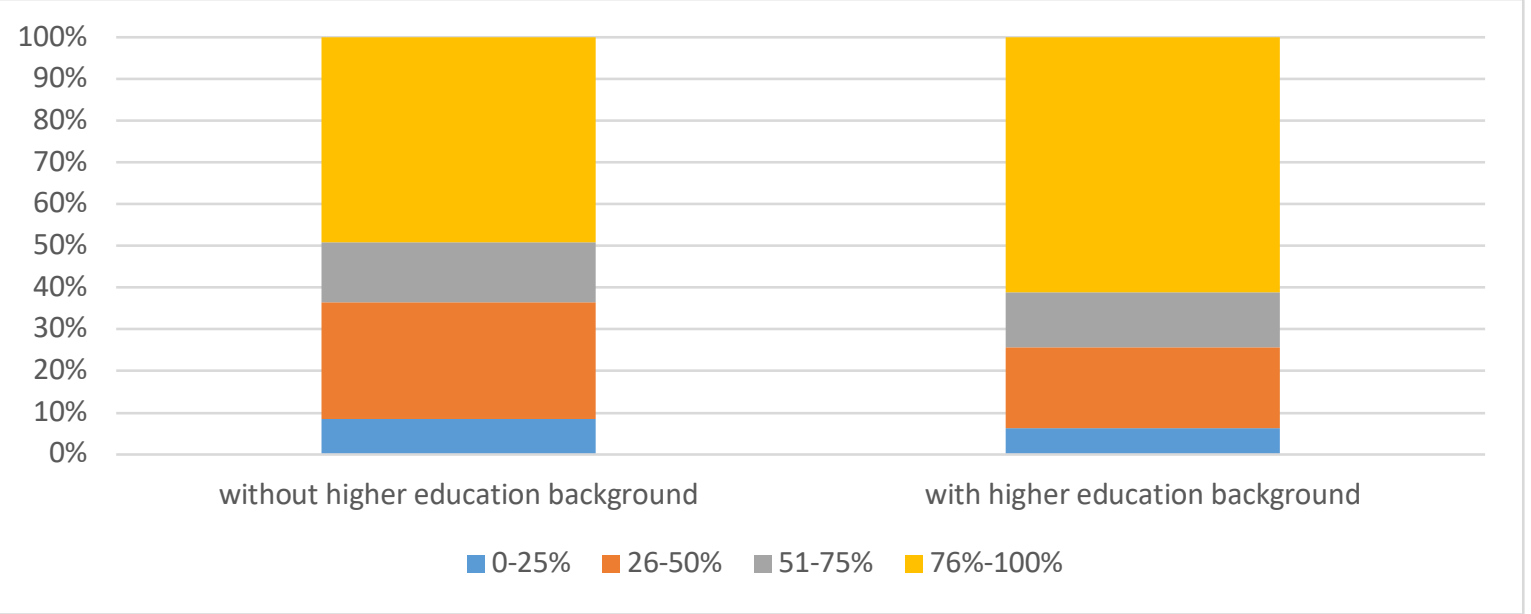

Diagram 2. Study related time budget according to parental education (percents, Eurostudent VI, N=7202).

We are aware of the fact that other independent variables (labour market presence, family engagement etc.) may shape this relationship, but similar empirical findings were revealed when we analysed the time budget of full-time students (Bocsi 2013'). Not only is the study-related time budget narrow, but first generation students also evaluate their study intensity as being lower. ${ }^{9}$ The questionnaire mapped further education plans with the following optional answers: continuation of studies within a year of finishing current study programme(s), continuation of studies at a later time, no continuation of studies, and undecided about continuation of studies. If we compare the proportion of the answers in the two subsamples, a significant difference can be shown in the case of the first (38.6 and $44.6 \%$ ) and the fourth response (30.5 and $25.8 \%$ ). First generation students do not have a negative but rather more of an ambiguous attitude toward further education, because no difference is found in the case of "no continuation of studies". The correspondence between drop out and parental education has been thoroughly explored (Pusztai 2018, Pusztai et al. 2019). Our empirical findings reveal a new segment of this relationship - undergraduates had to name the reasons for interrupting the current (main) study programme for at least two consecutive semesters. Therefore, the number of the respondents was lower (Diagram 3) in this case.

\footnotetext{
${ }^{8}$ The least time spent in the field of "learning" belongs to the lowest educational level (elementary school) of mothers and fathers. The pattern of relationship is not linear (Bocsi 2013).

9 The percentage of 'low intensity' students in the subsample "without higher educational background" is $29 \%$ and in the subsample "with higher educational background" it is $25.4 \%$. The proportion of 'high intensity' students in the first group is $24.6 \%$, and in the second is $31.9 \%$.
} 


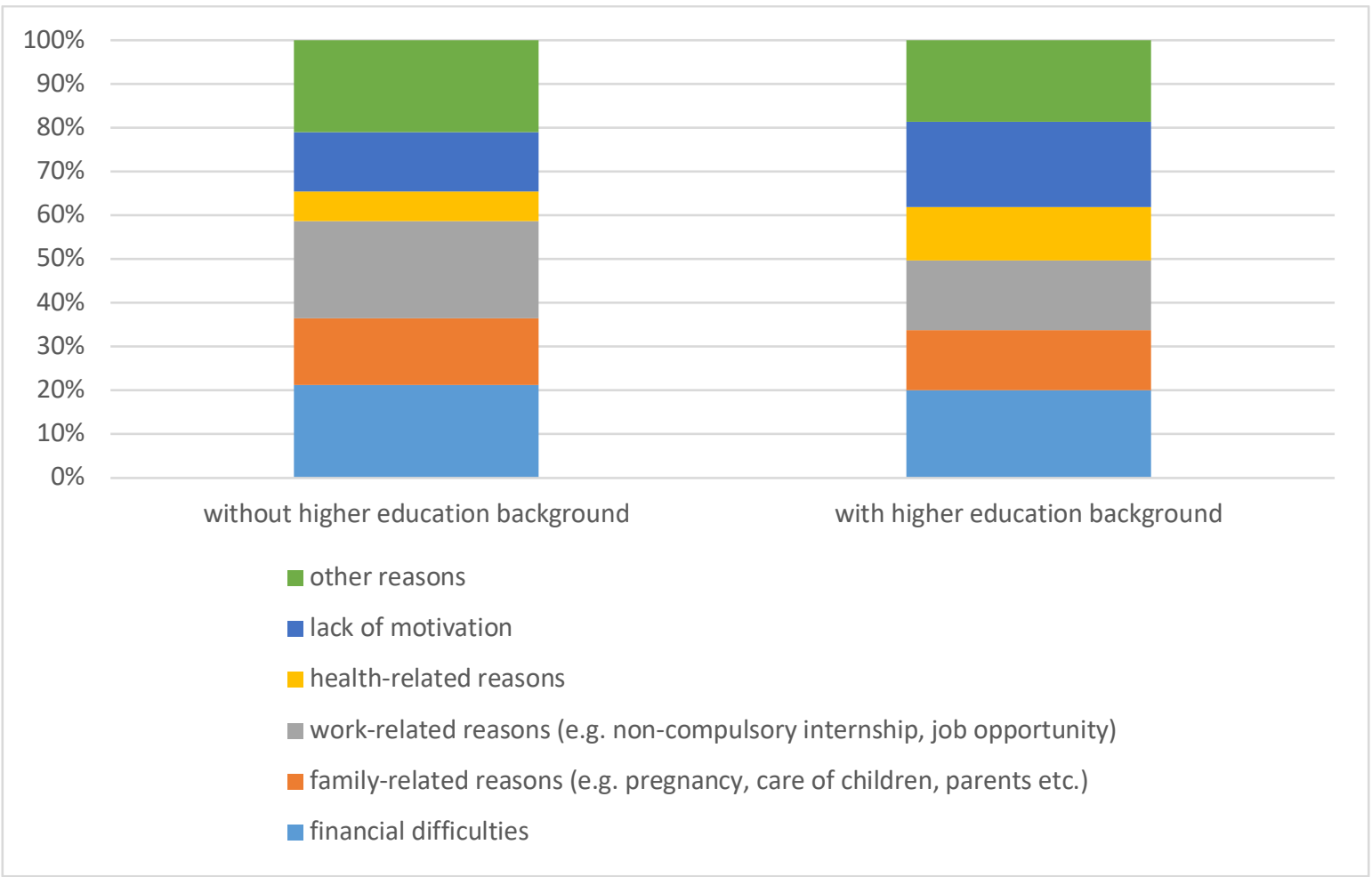

Diagram 3. Students' reasons for interruption, according to parental education ( $\mathrm{N}=280$ and 373 , percents, Eurostudent VI)

Some differences may be explained by the commitments of the older cohort (family-related reasons, work-related reasons) but the most interesting pattern is the "lack of motivation". This data modifies the earlier picture of first generation students and the learning process and highlights the external, compelling context(s) which can reduce the probability of finishing the course.

\subsection{The Hungarian Youth Research project}

In this phase of the analysis not only the features of the first generation students were analysed but also longitudinal processes. We have used two waves of the Hungarian Youth Research project from 2012 and 2016. We will focus on the proportion of first generation students within the student population and try to describe this subsample in terms of sociodemographic variables (parental educational level, type of settlement and parental classification). If we want to give an exact picture of the transformation of first generation students, changes in Hungarian youth must be investigated, too - so we will also present the features of the whole sample, where possible.

As a first step, we identified three subsamples: young people with a non-intellectual background (without a degree, $\mathrm{N}^{2012}=451, \mathrm{~N}^{2016}=394$ ), a mixed background (one parent has a degree and the other does not, $\mathrm{N}^{2012=150,} \mathrm{~N}^{2016}=143$ ) and an intellectual background ( $\mathrm{N}^{\left.2012=150, \mathrm{~N}^{2016}=193\right) .10}$

In the theoretical part, the level of social mobility and educational policies were briefly described, so before the analysis we assumed that the student population shows the marks of closure. Diagram 3 delineates the proportions of the three subsamples in a longitudinal comparison.

\footnotetext{
${ }^{10}$ The proportion of men in the first generation student subsample was 45.6 in 2016 . This proportion is slightly lower than in the case of the full-time student sample (48.8).
} 

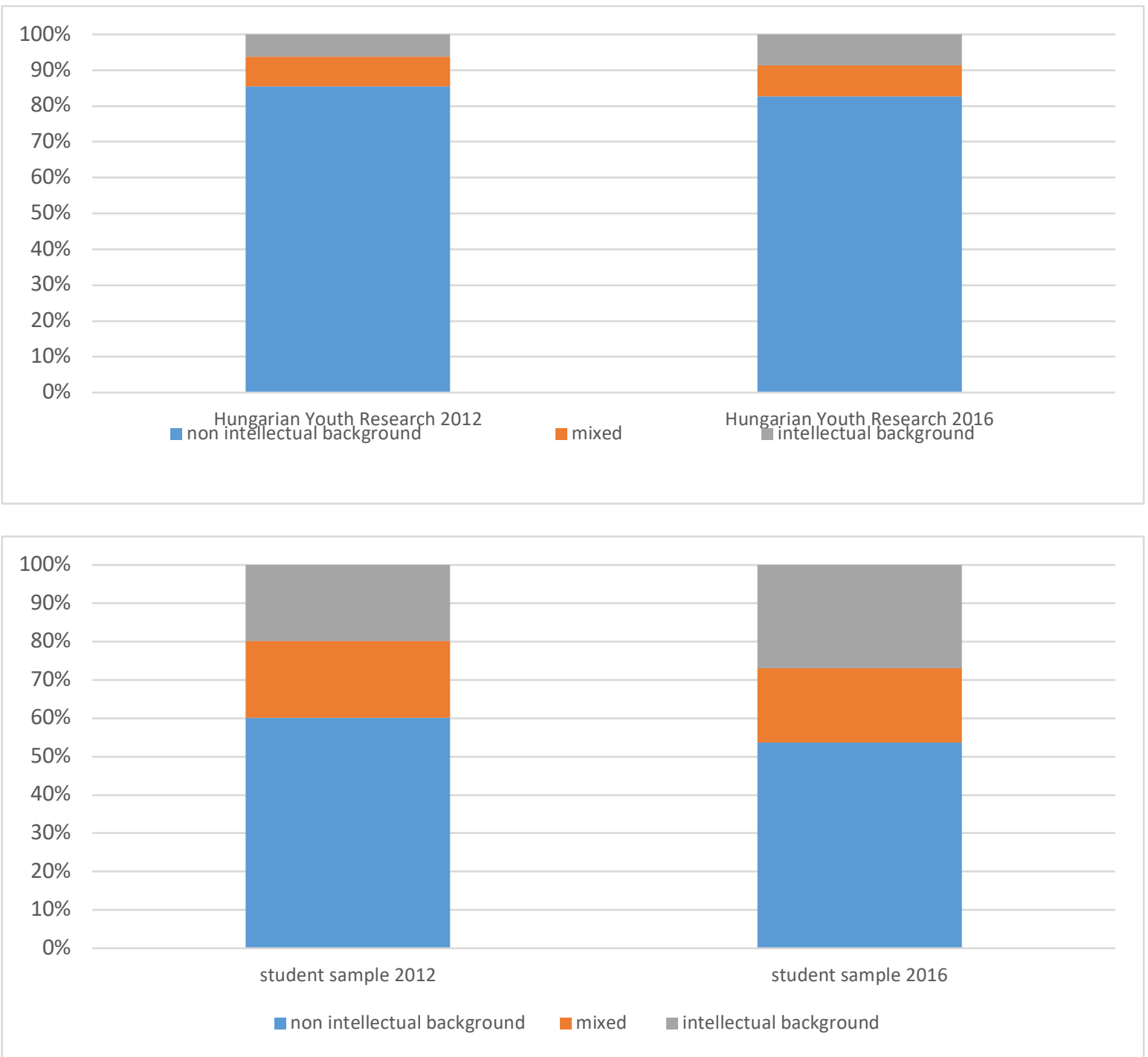

Diagram 3. The parental educational background of Hungarian youth and the student population in 2012 and 2016 (Hungarian Youth Research, N2012=8000 and 751, N2016= 8000 and 773, percents)

Due to the expansion in education, the level of the parental background increased between the two waves of the research. The proportion of those with a lower parental education level was above 82 percent in 2016 and the proportion of those with an intellectual background grew from 6.2 to 8.6 percent. Naturally, the student population has always had a specific and higher social base. The proportions of the subsamples were $60.1 \%$ (non-intellectual), $20 \%$ (mixed) and $19.9 \%$ (intellectual) in 2012. This pattern differs from our earlier empirical findings (Eurostudent VI) since only full-time students were included in this analysis. If we compare the changes in the proportions from 2012 to 2016, we can detect that they were more significant in the student population, which may implies a process of social closure.

Regional inequalities and the distance between villages and cities are important dimensions of the social stratification theories. The extent of regional inequalities are quite significant in Hungary. Regional and educational inequalities can interlock: empirical findings revealed the fact that the achievement of children is appreciably lower in the villages in Hungary (Szabó et al. 2018). The patterns of parental education are implicitly lower in the villages and the parental educational level has a strong effect on students' achievement in Hungary, according to the PISA test (Hungary. Student Performance 2018). So young people from villages are in multiple disadvantageous circumstances if they wish to enter a higher education institution.

The next step is a survey of the relationship between the types of settlements and first generation students. Diagram 4 represents data related to this approach. 


\section{2}
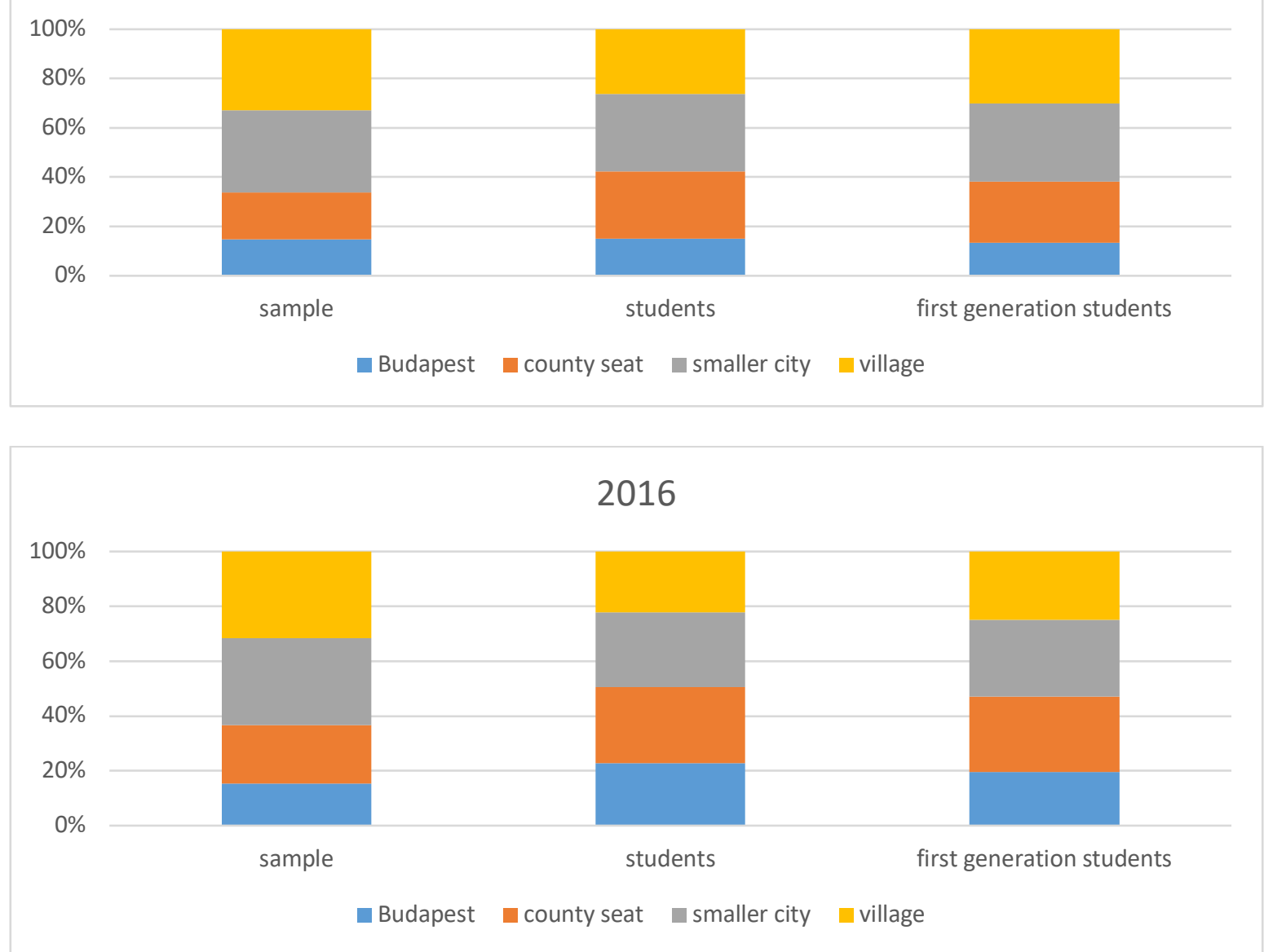

Diagram 4. "Student population and first generation students, according the type of the settlement" (Hungarian Youth Research, N2012=8000, 751 and 451, N2016=8000, 773 and 394, Hungarian Youth Research 2012 and 2016, percents)

We can state that not only the students' but the first generation students' sample too would be transformed if we used the settlement criteria, and this alteration seems to be more remarkable than in the whole sample. This shift may highlight the fact that first generation students from villages face a significant barrier during the process of social mobility. This barrier seems to be more easily surmountable from Budapest and the main towns.

The specialist literature distinguishes the notions of first generation students and working class students, and we saw that these are not equivalent. The phenomenon of resilience (Ceglédi 2012) remains closer to students from a working class background because parents without a degree can be white collar workers as well, and these parents are working in positions which would actually require a degree. The chances for social mobility are not equal in these situations; however, if we only use the category of "first generation students", the inner transformation of the population may remain hidden. Diagram 5 shows us the classification of mothers. 

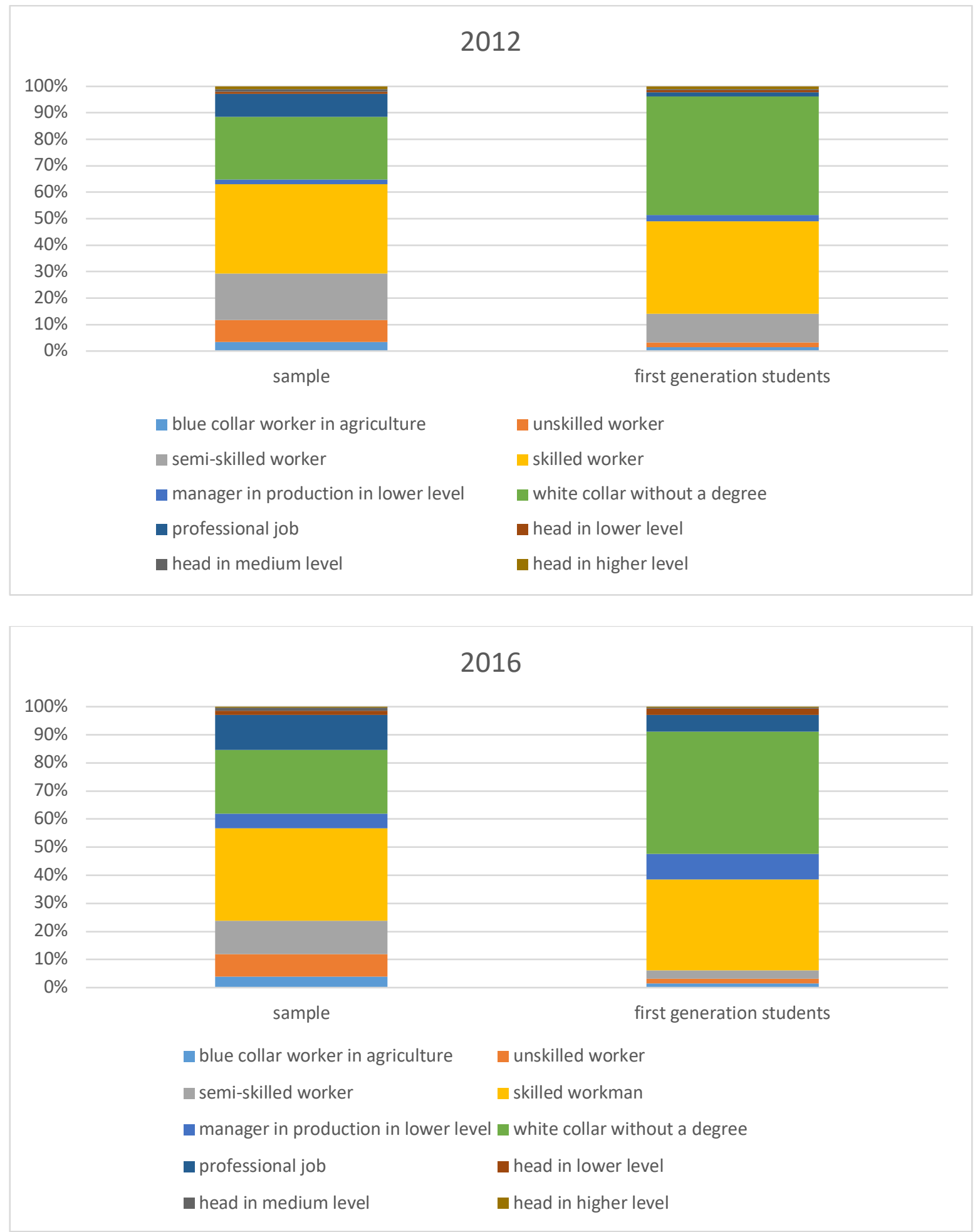

Diagram 5. "Mothers' classifications in the sample and the first generation student subsample" (Hungarian Youth Research, N2012=8000 and 751, N2016=8000 and 773, percents)

Of course, the professions with higher prestige were not frequent among first generation students in 2012, nor in 2016. The most populous category is skilled workers and white collar workers without a degree - this second category refers to "first generation students", and to a lesser extent to "working class students". The proportions of the lowest three categories are not important especially in 2016 (about 3\%). From these classification levels higher education seems to be almost inaccessible.

If we analyse the fathers' educational level in detail, we also find the traces of supposed closure (Diagram 6). The shift in the student population is considerable during this period: the proportion of 
fathers with a degree increased from 31.5 to $37.5 \%$ and the cumulative percentage of fathers with a qualification below secondary grammar school fell from 29.5 to $21.4 \%$. If we separate the first generation students, the robust proportion of "higher" categories (secondary grammar school, higher level vocational training) is salient. Access from the lower categories to higher education is also restricted from the educational level perspective.
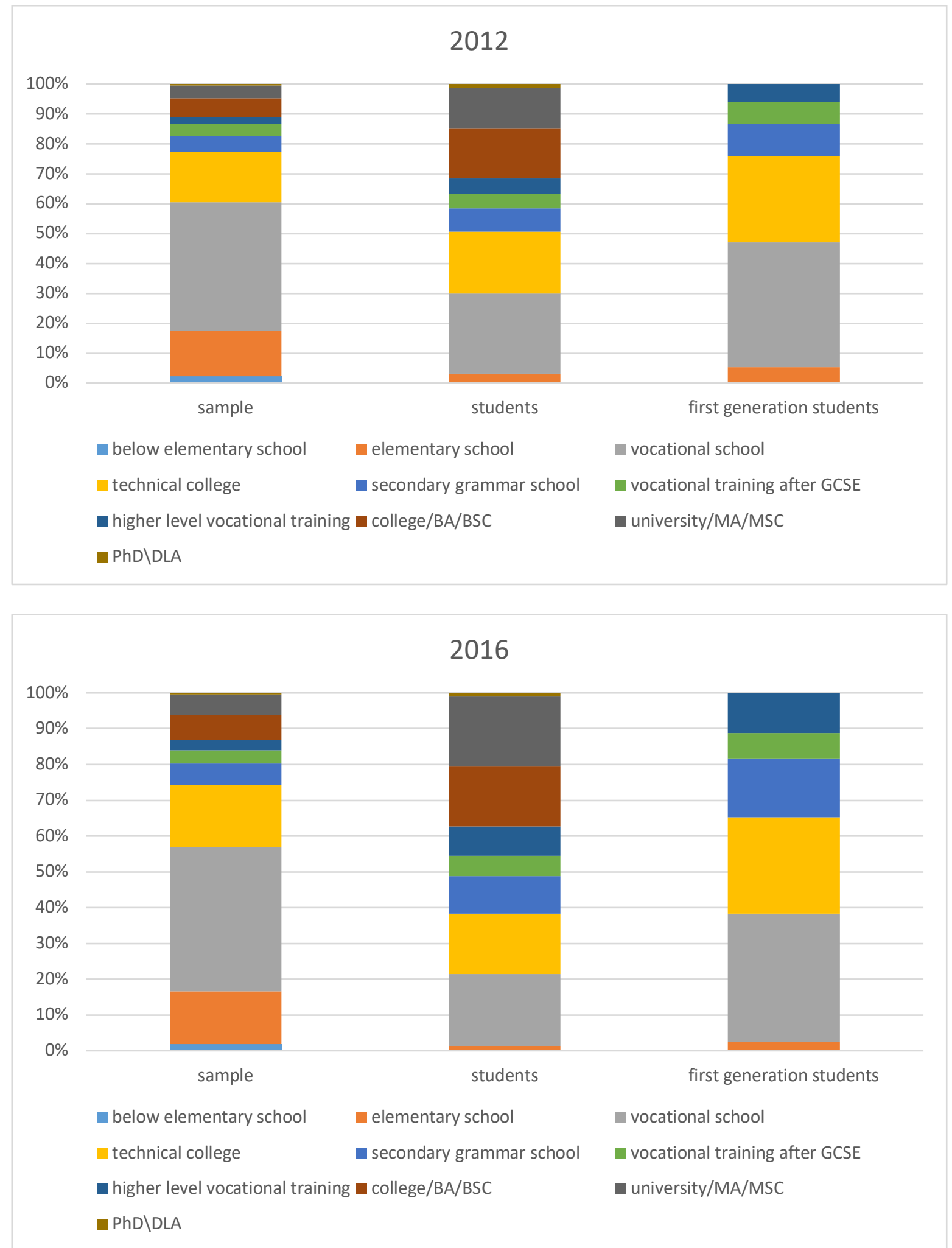

Diagram 6. "Fathers' educational level in the database, the student sample and first generation student subsample" (Hungarian Youth Research, N2012=8000, 751 and 451, N2016=8000, 773 and 394, percents) 


\section{Conclusions}

\subsection{Limitations}

Naturally our analysis has got limitations. A quantitative approach will be used during this analysis, but we are aware of the fact that some aspects of this issue cannot be accessed from this perspective. The observations, feelings and narratives of these undergraduates are frequently analysed, and these empirical findings we have used only in the theoretical framework. These percents are not tested for statistical significance due to the fact that the we used the Eurostudent VI. Database only on the website of the research and the data come from two different database in the case of Hungarian Youth Research. We could not describe some important segments of the theories (e.g. motivation toward higher education, the supports of parents) because this was not the main aim of the research project.

\subsection{Summary}

The specialist literature provides a frame in which the circumstances of first generation students can be interpreted. Some segments of these theories focus on the pre-college factors and others describe the world of the campus. While we conducted a quantitative comparison which only covers university years, we must be aware that explanations for these features are embedded in earlier circumstances and these effects are permanent. The handicap facing these students can be shown after their graduation, too.

These handicaps can be reduced with efficient educational and institutional policies. Since the last decade we can observe ambiguous tendencies in Hungarian higher education. If we look at campuses there are significantly more resources available for first generation students than 20 years ago. The network of Roma Colleges for Advanced Studies has emerged, several loans and scholarships are accessible and different mentor programmes have been operating. But the attitudes of institutions and faculties toward first generation students differ, and students do not have similar access to information about these opportunities. Some institutions in the lower segment of higher education had no other choice but to build a supporting system due to the transformation of the student base after the millennium. This shift obviously creates new behavioural patterns and practices for lecturers, as well (other types of communication, other methods in teaching, taking part in mentor programmes etc.). In a favourable case the transformation of institutions overlaps with the central educational policies and so available resources or central efforts can establish good practices in institutions.

However, these facilities tend to operate on campus and after entry to higher education. Our own empirical findings supposed a closure in the population of students and during this shift the typical resilience pathway seems to be less frequent. This transformation alludes to the fact that central and institutional efforts after entry are not enough. A significant number of possible students choose a lifepath which eventually avoids higher education or they are forced to avoid further learning due to external, compelling circumstances. Therefore the recruitment activities of institutions have to improve the elements and information about institutional policies and available resources which focus on students from lower social groups. The cooperation of secondary schools and universities is important because teachers from secondary schools have to encourage these young people and provide information for their parents, as well. These teachers have a key role in this process due to the lack of knowledge about higher education in the families concerned. Experiences show that the common events of universities and secondary schools make the transition to the level of tertiary education easier and can alter the "strange" features of higher education.

At the same time, the nationwide educational policy shows features which can amplify the closure of higher education. The transformation of the tuition fee system, the recurrence of state funded places in training courses (especially in the case of high-prestige disciplines - law, economics etc.) probably generated this process after 2010. Educational sociology highlights the fact that one very important skill is to be able to take a long-term view of the education system, because this skill helps us to make good decisions. During an intergenerational social mobility process parents have to make many good decisions - without enough information. The theoretical part of this study pointed 
out that the rate of social mobility is lower in Hungary, so these kinds of effects - i.e. the effects of both teachers and institutions - on parents and young people can make the entire society more open.

If we analyse the features of the student population in detail, marked differences can be found. The proportion of first generation students is clearly different at bachelor and master levels (or in case of combined bachelor and master courses) but certain faculties, smaller institutions or training programmes have higher proportions of these students. This situation is typical in the field of teacher education for lower ISCED levels, or in the field of social work. In 2017, in one of the faculties of the University of Debrecen there were no students with an intellectual background among full-time undergraduates during their third semester. ${ }^{11}$ In this case, the first generation students determine the main features of the student population. This can shape the transformation process of students' identity (maybe to a lesser degree) and generate a narrower distance between families and university - especially in the case of white collar workers' children. In this case, an inclusive environment may be created in every segment of the college or university, because this is the only possible way of functioning.

Our future plan is to describe this population with qualitative techniques and at local levels. Perhaps it is no accident that the field of experiences, the transformation of identity and the narrative of integration can be well described with interviews, and at the same time local practices can become more recognizable. Moreover, the quantitative approach can be a base for these further analyses, and in our opinion these statistics highlight the importance of this topic.

Funding: This study was supported by the János Bolyai Research Scholarship of the Hungarian Academy of Sciences.

Supported by the UNKP 18-05 New National Excellence Program of the Ministry of Human Capacities.

Project no.123847 has been implemented with the support provided from the National Research, Development and Innovation Fund of Hungary, financed under the K_17 funding scheme.

Acknowledgments: Kutatópont made the database of Hungarian Youth Research 2012 and 2016 available. https://kutatopont.hu/

Conflicts of Interest: The author declares no conflict of interest. The funders had no role in the design of the study; in the collection, analyses, or interpretation of data; in the writing of the manuscript, or in the decision to publish the results.

\section{References}

1. Bauman, Z. (1987). Legislators and Interpreters: On Modernity, Post-modernity and Intellectuals. Cambridge: Polity Press.

2. Berlinger, E. \& Megyeri K. (2015). Mélyszegénységből a felsőoktatásba. Közgazdasági Szemle, 62(6), 674-699.

3. Bocsi, V. (2013). Az idő a campusokon. Szeged: Belvedere Meridonale.

4. Bocsi, V. (2018). (Kárpát-medencei) erőforrástérkép - magyar fiatalok az oktatás világában. In Székely L. (Ed.), Magyar fiatalok a Kárpát-medencében. Magyar Ifjúság Kutatás 2016. Budapest: Kutatópont Kft. 183-204.

5. Bok, D. (2003) Universities in Marketplace. The Commercialization of Higher Education. Princeton University Press: Princeton and Oxford.

6. Burlutskaia, M. G. (2014): Higher Education as a Means of Upward Social Mobility. Russian Education and Society, 56(4), 52-63.

7. Ceglédi, T. (2012): Reziliens életutak, avagy a hátrányok ellenére sikeresen kibontakozó iskolai karrier. Szociológiai Szemle, 22(2), 85-110.

8. Christie, F. (2016). Career Guidance and Social Mobility in UK Higher Education. British Journal of Guidance and Counselling, 44(1), 72-85.

9. Cooper, L. (2013). Women in Higher Education: Perspectives of Middle-Class, Mother Daughter Dyads. Gender and Education, 25(5), 624-639.

10. Csapó B., Molnár Gy. \& Kinyó L. (2009). A magyar oktatási rendszer szelektivitása a nemzetközi összehasonlító vizsgálatok eredményeinek tükrében, Iskolakultúra, 19(3-4), 3-13.

${ }^{11}$ This faculty is the author's workplace. (Intellectual background: neither the father nor the mother has a degree.) 
11. Education GPS, OECD (2020). Hungary. Student Performance 2018. Retrived from: http://gpseducation.oecd.org

12. Eurofound (2017). Social Mobility in the EU. Luxembourg: Publications Office of the European Union.

13. Eurostudent (2016). Retrived from: http://database.eurostudent.eu/

14. Fényes, H. (2009). Nemek szerinti iskolai eredményesség és férfihátrány-hipotézis. Magyar Pedagógia, 109(1), 77-101.

15. Fitzgerald, T., White, J. \& Gunter, H. M. (2012) (Eds.). Hard Labour? Academic Work and the Changing Landscape of Higher Education. Bingley: Emerald Group.

16. Graham, G. (2005). The Institution of Intellectual Values. Realism and Idealism in Higher Education. Inprint Academic: Charlottesville.

17. Haney, D. P.(2008). The Americanisation of Social Sciences. Intellectuals and their Responsibility in the Postwar U.S. Temple University Press: Philadelphia.

18. Haveman, R. (2006). The Role of Higher Education in Social Mobility. The future of Children, 16(2), 125-150.

19. Hegedüs R. (2018). Hátrányos helyzetúek a közép-és felsőoktatásban. PhD Thesis. Debrecen, Hungary: University of Debrecen, Doctoral School of Humanities.

20. Hrubos I. (2012). Az egyenlőtlenségek új színterei a felsőoktatásban, Iskolakultúra, 22(1-2), 57-72.

21. Hrubos I. (2014). Expanzió - határok nélkül. Educatio, 23(2), 205-215.

22. Hudson, A. (2005). Intellectuals for Our Times. In Cummimngs, D. (Eds.), The Changing Role of Public Intellectual. Routledge: New York. 33-50.

23. Karády V. (2012). Az értelmiség kialakulásának kezdetei Magyarországon a 19. században. In Karády V. \& Nagy P. T. (Eds.), Iskolázás, értelmiség és tudomány a 19-20. századi Magyarországon. Budapest: WJLF. 13-31.

24. Jacoby, R. (2000). The Last Intellectuals: American Culture in the Age of Academe. Basis Books: New York.

25. Laemmli, T. (2011). "Getting Educated”: Working Class and First Generation Students and the Extra-curriculum. Sociology of Honour Projects. Paper 32. http://digitalcommons.macalester.edu/soci/ honors/32

26. Lagermann, E. C. \& Lewis, Harry (2012) (Eds.,). What College for? The Public Purpose of Higher Education. Columbia University: New York - London: Teachers College.

27. Lehmann, W. (2012). Extra-Credential Experiences and Social Closure: Working Class Students at University. British Educational Research Journal, 38(2), 203-2018.

28. Kolosi T. (1987). Tagolt társadalom. Budapest: Gondolat.

29. Kozma T. (2004). Kié az egyetem? Budapest: Új Mandátum Press.

30. Marginson, S. (2007). Globalisation, the „Idea of a University” and its Ethical Regimes. Higher Educational Management and Policy, 19(1), 1-15.

31. Moreau, M-P. \& Leatwood, C. (2006). Balancing Paid Work and Studies: Working (-class) Students in Higher Education. Studies in Higher Education, 31(1), 23-42.

32. Oldfield, K. (2012). Still Humble and Hopeful: Two More Recommendations on Welcoming First Generation Students to College. About Campus, November - December, 2-14.

33. Szabó L., Szepesi I., Takácsné Kárász J. \& Vadász Cs. (2018). Országos Kompetenciamérés 2017. Budapest: Oktatási HIvatal. Retrived from: https://www.kir.hu/okmfit/files/OKM_2017_Orszagos_jelentes.pdf

34. Pearce, J., Down, B. \& Moore, E. (2008). Social Class, Identity and the Good Student: Negotioating University Culture. Australian Journal of Education, 52(3), 257-271.

35. Pusztai, Gabriella (2018) The Role of Intergenerational Social Capital in Diminishing Student Attrition. Journal of Adult Learning Knowledge and Innovation, 2(2), 1-7.

36. Pusztai G., Fényes, H., Szigeti, F. \& Pallay, K. (2019). Who the Dropout students are? Central European Journal of Educational Research, 1(1), 8-16.

37. Reay, D., Crozier, G. \& Clayton, J. (2010). „Fitting in' or Standing out”: Working Class Students in UK Higher Education. British Educational Research Journal, 36(1), 107-124.

38. Romsics I. (2017). Magyarország története. Budapest: Kossuth Kiadó.

39. Pike, G. R. \& Kuh, G. D. (2005). First and Second Generation College Students - A Comparison of their Engagement and Intellectual Development. The Journal of Higher Education, 76(3), 276-300.

40. Reul, S. (2005). What Genius Once Was: Reflections on the Public Intellectuals. In Cummimngs, D (Eds.), The Changing Role of Public Intellectual. New York: Routledge, 24-32.

41. Rubin, M. \& Wright, L. Ch. (2015). Age Differences Explain Social Class Differences in Students' Friendship at University: Implications for Transition and Retention. Higher Education, 70(3), 427-439.

42. Tímár J. \& Polónyi I. (2006). A pedagógusprobléma. Új Pedagógiai Szemle, 56(4), 15-31. 
43. Soria, K. \& Bultman, M. (2014). Supporting Working-Class Students in Higher Education. NACADA Journal, 34(2), 51-62.

44. Szelényi I. (1990). A kelet-európai újosztály stratégia távlatai és korlátai: Az értelmiség útja az osztályhatalomhoz önkritikus felülvizsgálata. In Szelényi I. Új osztály, állam, politika. Budapest: Európa Kiadó. 51-98.

45. Terenzini, P. T., Springer, L., Yaeger, P. M., Pascarella, E. T., \& Nora, A. (1996). First-Generation College Students: Characteristics, Experiences, and Cognitive Development. Research in Higher Education, 37(1), 122.

46. Tiele, T., Pope, D., Singletin, A., Snape, D. \& Stanistreet, D. (2017). Experience of Disadvantage: the Influence of Identity on Engagement in Working Class Students' Educational Trajectories to an Elite University. British Educational Research Journal, 43(1), 49-67.

47. Weidman, J. C.(2006). Socialisation of Students in Higher Education. In Clifton, C., C. \& Ronald, S. C. (Eds,), The SAGE Handbook for Research in Education: Engaging Ideas and Enriching Inquiry. Thousand Oaks, CA: SAGE. 253-262.

(C) 2020 by the author. Submitted for possible open access publication under the terms and conditions of the Creative Commons Attribution (CC BY) license (http://creativecommons.org/licenses/by/4.0/). 